\section{VI \\ VERSITA}

Folia Oeconomica Stetinensia

DOI: 10.2478/v10031-012-0002-0

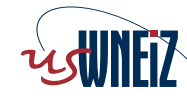

Wydzial Nauk Ekonomicznych i Zarządzania Uniwersytetu Szczecińskiego

\title{
SUSTAINABILITY AS THE DIRECTION FOR THE LONG-TERM SUCCESS IN BANKING: POLAND VS. CROATIA
}

\author{
Prof. Edyta Rudawska \\ University of Szczecin \\ Faculty of Economics \& Management \\ Department of Marketing \\ Mickiewicza 64, 71-101 Szczecin, Poland \\ e-mail: edyta@rudawska.pl
}

\section{Prof. Sanda Renko}

University of Zagreb, Croatia

Faculty of Economics \& Business

Department of Trade

10000 Zagreb, Trg J. F. Kennedyja 6, Hrvatska

e-mail: srenko@efzg.hr

\begin{abstract}
Dynamic environment forces companies to develop new approaches to establishing objectives and to develop management practices. Apart from doing profit-making activities, companies are forced to undertake activities aiming at their long-term sustainable development. As a result of deregulation and globalization, the banking sector had to accept the postulations of sustainable development and to keep their position on the market through establishing lasting relationships with customers, environment organizations, employees and a local community. The main goal of this paper is to explore implications of sustainability on the banking sector. Based on the research on the sample of 33 bank managers, the paper is trying to find out whether there are similarities in sustainability aspects in the banking sectors of Poland and Croatia. The findings of the papers suggest that banks in Poland express stronger need to take into account the environmental, social and economic concerns comparing to banks in Croatia.
\end{abstract}

Keywords: sustainability, environment, society, ecology, banks, Poland, Croatia.

JEL classification: G21, M31. 


\section{Introduction}

The overall economic collapse which started in 2007, had a strong impact on all segments of business and social life. The competitive battle on the market has become harder than ever because increasing domestic and international competition resulted in a large offer in some economic areas. On the other hand, there is decreasing demand caused by unfavourable economic conditions and consumer pessimism. Therefore, companies should take more effort to survive on the market. They have to define a strategy that could position them in front of other market subjects. As the global raise in environmental and social concern forced companies to express greater attention toward environmental protection and toward society as well, numerous "smart" companies used this concept to create their competitiveness on the market. The process of making sustainable development an important issue on the world stage started in 1987 with the report by the United Nation`s Brundtland Commission. The Commission identified a number of "common challenges" facing the Earth, such as: population and human resources, food security, species and ecosystems, energy, industrial development and urbanization. Accordingly, Goes et al. ${ }^{1}$ note that the term sustainability, generally means that the "environmental management" manages the environmental resources in order to save them, thereby ensuring that future generations find an environment compatible with their needs. On the other hand, Bebbington ${ }^{2}$ draws attention to making equal sustainable development a "good environmental management". Hopwood et al. ${ }^{3}$ point it out, in contrast to the predominant outlook of the last hundred years that has been based on the lack of balance between socio-economic and environmental policies. Stefanescu et al. ${ }^{4}$ argue that this new concept of human development implies the establishment of a suitable economic policy, monitoring it and encouraging investment and savings. Particularly, the banking system could contribute to making the growth sustainable. Montes ${ }^{5}$ investigates the example of a bank which is an alternative "socially responsible" bank that specializes in financing environmentally profitable projects.

The main goal of this paper is to explore the implications of the sustainability on the sector where competition has a specific character due to a particular role of public trust - that is the banking sector. The authors of the paper used banking sectors of Poland and Croatia to find out whether there were similarities between these sectors in two countries in transition that came from the same socio-political constitution. The former already is a EU member while the latter is the EU candidate in the last phase of negotiation.

The paper begins with a short theoretical background where the authors give the insight into the concept of the sustainable development and the activities that institutions are forced 
to undertake when they aim at their long-term sustainable development. The paper analyzes economic, ecological and social dimensions of sustainable development. The short overview of the Polish and Croatian banking sectors with the emphasis on sustainable development activities is presented.

Then, the results of the study on the sustainability aspects in the banking sectors of Poland and Croatia are discussed. Focusing on the financial sector whose institutions are of public trust and cannot be engaged in a fierce struggle for the position the market, this paper gives us insight into some non-material factors such as relations with various market subjects (customers, employees, ecology and social pressure groups as well as local communities) where banks can obtain their competitive advantage. They are unique, difficult to imitate and are characterized by a limited substitution because they are based on trust and emotions as well as they are not subject to ownership, therefore they cannot be traded.

\section{The concept of sustainability}

The meaning of the concepts of "sustainable development" and "sustainability" is very complex in nature, and they are still the topics of many scientific debates. Due to its complexity the term is a widely used phrase and idea. It has different meanings and provokes many different responses ${ }^{6}$.

Knezevic et al. ${ }^{7}$ suggest that basically the concept of sustainability is a political and global idea whose origins are related to the environmental problems of less developed countries. For the first time the concept was used by Barbara Ward in the $1960 \mathrm{~s}^{8}$, but the media attention grew after the Cocoyoc Declaration (the joint conference of the United Nations Environmental Program - UNEP and the United Nations Commission on Trade and Development - UNCTAD was held in Cocoyoc in Mexico) in 1974 where some relationships were found between social welfare and environmental concers. From its early begginings until nowadays the concept of sustainable development has expanded its scope and value by incorporating challenges in the area of economic growth, human-environment relationships, increased information, new technologies, etc.

Nowadays, it is often emphasized that an enterprise performs several roles on the market. According to Drucker, there are three main tasks that any management has to perform, i.e. to meet economic objectives, to ensure the productivity of work and the satisfaction of workers, and to manage social impacts and discharge social responsibilities. He indicates that "free enterprise cannot be justified as being good for business; it can be justified only as being good 
for society" ". Therefore, enterprises should contribute to the environment, and fulfill social and ecological objectives along the economic ones.

Apart from profit-making activities, enterprises are forced to undertake the activities aiming at their long-term sustainable development. Such a situation is forced by growing pressure from demanding customers, local and government authorities or community organizations, technological progress, new regulations, globalisation, or media attention. Enterprises take into account long-term interests of their stakeholders. Therefore, they voluntarily incorporate social and environmental aspects into their daily activities and relations with their stakeholders. However, every enterprise applies this idea in its own way depending on its competencies, resources, kinds of stakeholders, and even its cultural traditions or social and environmental situation of the area where it operates ${ }^{10}$. This approach refers to the Lisbon strategy set at the Lisbon Summit in 2000 which was supposed to transform Europe into the most competitive and dynamic knowledge-based economy in the world, capable of sustained and sustainable economic growth, with more jobs and greater social cohesion. As a result of inefficient activities and the world's economic crisis, this strategy failed to achieve its aims and the new Europe 2020 strategy was launched in March 2010. The Europe 2020 strategy puts forward three mutually reinforcing and interdependent priorities to be implemented through concrete actions at the EU and national levels:

1) smart growth realized by fostering knowledge, innovation, education and digital society;

2) sustainable growth making production more resource efficient while boosting competitiveness;

3) inclusive growth referring to raising participation in the labour market, the acquisition of skills and the fight against poverty.

Although enterprises are frequently pressurized to improve financial performance, they cannot limit their activities in making profit and increasing their market value. Managers cannot favour the interests of their enterprise and its shareholders more than the interests of other stakeholders.

Sustainable development has been defined in many ways. But the most frequently quoted definition is the one proposed in 1987 by the World Commission on Environment and Development (Brundtland Commission 1987)"11: "Sustainable development is development that meets the needs of the present without compromising the ability of future generations to meet their own needs. It contains within it two key concepts:

- the concept of needs, in particular the essential needs of the world's poor, to which overriding priority should be given; and 
- the idea of limitations imposed by the state of technology and social organization on the environment's ability to meet present and future needs".

Stanley believes that sustainable development has proven problematic in practice due to its nature and due to many interpretations. He argues that the lack of a widely accepted policy framework for achieving sustainable development has resulted in ad hoc approaches in various countries $^{12}$. Roome and Bergin point out the lack of theoretical clarity about what sustainable development meant for industrial organizations ${ }^{13}$.

\section{Economic, ecological and social dimensions of sustainable development}

Sustainable development on the micro scale covers company development as the result from undertaking activities in economic, ecological and social dimensions.

Economic dimension relates to the transformation into a competitive and dynamic knowledge-based economy, assuming that knowledge, being the most valuable asset, is the key to competitiveness. It relates to pursuing economic goals in the long term while satisfying customers' needs lawfully and ethically. It also takes account of the side effects of undertaken decisions. For an enterprise, the economic aspect means the need for creating and managing relations with customers and employees considering ethics and legal regulations ${ }^{14}$. Thus, the enterprise is able to provide itself and its owners with long-term interests. The enterprise cannot be engaged in the protection of the environment or supporting charities if these activities hinder its financial liquidity. Social responsibility cannot disregard economic limits.

Ecological dimension focuses on the environmental protection issues, since the longterm development of enterprises may be hindered by environmental degradation. This aspect relates to business activities conducted in accordance with ecological requirements, as well as supporting ecological organizations and campaigns. Also, ecologically sustainable development means the application of responsible practices relating to managing natural resources in the production process ${ }^{15}$. A company should not only follow environmental protection regulations, but also undertake ecological initiatives in order to create better future for next generations. Ecologically sustainable development also involves streamlined production processes, efficient waste management and the recognition of consequences of undertaken activities, shown through the attention devoted to the needs and well-being of future generations. The aspects that should be emphasized include the assessment of the use of air-conditioning in office space, the choice of heating systems (conventional heating, solar panels), the choice of window frames, electricity management in office space (the use of daylight, installation of motion detectors and time lag 
switches in frequently used areas, the use of energy saving lighting), water use management, waste management, etc. Studies indicate that a $20 \%$ reduction in energy use turns into better financial performance to the same extent as a $5 \%$ increase in turnover ${ }^{16}$. Therefore, even a modest increase in energy and water use efficiency can significantly influence the environment and improve a company's financial performance.

Social dimension involves directing attention to employees, improving their qualifications, conducting active employment policies, and promoting the welfare of employees. This aspect includes social commitment realized through supporting charities and maintaining relationships with a local community ${ }^{17}$. Another important aspect is preventing social exclusion by providing jobs and education, medical care, or combating discrimination. Charities should be supported according to the following rules ${ }^{18}$ :

1. The best recipients of donation should be chosen as far as the use of means for particular social goals is concerned.

2. Other donators should be attracted. Charity organizations cooperate with business partners, i.e. suppliers, consumers, non-governmental organizations, thus accumulating financial means, gathering more information and improving communication. Thus, social goals are worked towards more effectively.

3. The situation of donation recipients should be improved. It can be improved especially when a company is able to integrate its acts of charity with its business activity, as is the case with companies operating in modern technologies, medical and food sectors. These sectors enable donated people to broaden their knowledge and improve their health. They also increase the demand for their services and goods.

4. Innovations should be developed and introduced. Resources, financial power and skilled staff enable companies to develop and introduce significant innovations, which can be used to attain social goals.

\section{The short overview of the Polish and Croatian banking sectors' situation}

Within the last two decades, the banking sector in Poland has undergone dynamic changes. It relates to the development from secure banking sector highly protected by state regulations into the competitive one. This situation forced banks to apply market methods of struggling for customers and creating their market position.

The end of 1980s was the crucial period for the Polish banking system. Then a new banking law was established and the transformation towards market economy began. The deregulation of 
this sector, being the result of reduced institutional and legal limitations and the liberalization, brought competition. A network of commercial banks emerged and they became autonomous as far as the scope of their activities, margins and interest rates. New rules of granting licences were introduced. They led to the creation of new banks, the privatization of the state-owned banks as well as to the flow of foreign capital and foreign financial institutions into the Polish banking sector. That created an unprecedente increase in competitiveness on the domestic market. The next bank law act was passed on 29 August $1997^{19}$. It sanctioned the positive tendencies happening on the market, which has been regarded as the fastest growing sector in the Polish economy. According to the National Bank of Poland, there are 69 commercial banks in Poland ${ }^{20}$. Five of them (PKO BP, Getin Noble Bank, Bank Pocztowy, Bank Ochrony Środowiska and BGŻ) are the banks with a majority of Polish capital. At the same time, there is a slight increase in the concentration of the market, which is a consequence of the fusion of two banks, i.e. PeKaO SA and BPH SA. Total assets of the banking sector at the end of 2009 amounted to over 1 billion zlotys. The share of the assets of five largest banks was at $44.5 \%$ and it is similar to the average of the European Union countries' banking sector. This ratio has fallen slightly over the past few years in Poland. The reason for this is undoubtedly an aggressive battle for customers of smaller banks. It is estimated that the degree of concentration in the Polish banking sector in the coming years will remain at the same level.

In Poland, the average of $60 \%$ of Poles use banking services nowadays. Since the late 1990s an increase in the share of foreign capital has been observed. Currently it reaches the level of about $70 \%$. Most of the Polish banks shares and ownerships status belonged to investors from the European Union. In 2010 the highest share belonged to investors from France and Germany (the share of foreign capital held was $16.2 \%$ and $14.9 \%$ respectively). Similar trends were found in all the countries acceding to the European Union since 2004. This is a result of the liberal licensing policy and the new legal facilities for the domestic banking sector. The bestknown strategic investors in the "Polish" banks are Banco Santander (BZ WBK and AIG Bank), UniCredit (Pekao SA), Citi Group (Citi), ING Group (ING Bank) and Credit Agricole (formerly known as Lucas Bank).

The image of the Polish banking service sector has been affected by the crisis. The research conducted by Pentor, which specializes in the research on a financial services market in Poland, indicates that a general view of Polish banking sector has deteriorated in the last months ${ }^{21}$. Almost $20 \%$ decline in positive opinions has been observed. The latest research on the banking services market in Poland has demonstrated an alarming fall in trust and credibility of the providers of financial services. The levels of security, credibility and trust have declined by $25 \%$ on average, 
compared to two years ago ( $31 \%$ in 2006 vs. $6 \%$ in 2009). Thus, we can conclude the banks in Poland are currently struggling with the crisis of public trust. In such a market situation financial institutions in Poland have been forced to intensify their struggle for customers and fight for developing and maintaining their market position.

However, despite the world financial crisis, the Polish banking sector recorded an increase in assets by $7.3 \%$ in 2009 . Table 1 shows the biggest banks in Poland.

Table 1. Banks operating on the Polish market

\begin{tabular}{|l|c|c|}
\hline \multicolumn{3}{|c|}{ Profit on banking operations (in thousand euro) } \\
\hline & 1-st quarter of 2011 & 4-th quarter of 2010 \\
\hline PKO BP SA & 632,067 & 660,626 \\
\hline PeKaO SA & 449,647 & 466,519 \\
\hline BZWBK & 217,621 & 229,276 \\
\hline BRE & 201,856 & 203,981 \\
\hline ING Bank & 178,299 & 174,792 \\
\hline Bank Handlowy w Warszawie & 150,421 & 155,738 \\
\hline Getin Noble Bank & 141,427 & 143,033 \\
\hline Millennium & 110,024 & 118,733 \\
\hline BPH & 126,440 & 143,724 \\
\hline Kredyt Bank & 96,206 & 102,951 \\
\hline Total & $2,304,009$ & $2,399,374$ \\
\hline
\end{tabular}

Source: Bank (2010).

The Croatian banking sector followed similar directions as banking in other transitioning countries. After the liberalization of their banking system in 1993, the number of banks increased together with the competition among them. Until the end of 1999 the change of banking system ownership was completed. In 2006 there were 34 banks operating in the banking sector of the Republic of Croatia (32 Commercial banks, and two savings banks) with even 90.8 percent bank assets owned by foreign shareholders ${ }^{22}$. Shareholders from Italy and Austria accounted for the largest share of bank assets, a little over $80 \%{ }^{23}$. Additionally, shareholders from France, Hungary, San Marino, Turkey, Switzerland and Serbia each had one bank in their ownership. According to Croatian National Bank methodologies ${ }^{24}$, 32 commercial banks deal both with the retail market and the credit market, and 2 savings banks deal with the retail market only.

Table 2 shows the largest banks in Croatia. It is obvious that the five largest banks accounted for a high $76 \%$ of the total assets (concentration ratio $\mathrm{C} 5$ ) suggesting a significant system concentration, typical of smaller countries and countries that have undergone $\operatorname{transition}^{25}$. 
Table 2. Banks operating on the Croatian market

\begin{tabular}{|l|c|c|}
\hline \multicolumn{1}{|c|}{ Bank } & Assets (EUR) & \% in total assets \\
\hline Erste \& Steiermärkische Bank d.d. & $7,127,141$ & 13.42 \\
\hline Hrvatska poštanska banka d.d. & $2,064,837$ & 3.89 \\
\hline Hypo Alpe-Adria-Bank d.d. & $5,421,483$ & 10.21 \\
\hline OTP banka Hrvatska d.d. & $1,683,808$ & 3.17 \\
\hline Privredna banka Zagreb & $8,965,292$ & 16.88 \\
\hline Raiffeisenbank Austria d.d Zagreb & $5,073,181$ & 9.55 \\
\hline Societe Generale Splitska banka d.d. & $3,567,272$ & 6.72 \\
\hline Volksbank d.d. & $1,049,099$ & 1.98 \\
\hline Zagrebačka banka d.d. & $13,530,227$ & 25.47 \\
\hline Ostale banke & $4,630,276$ & 8.72 \\
\hline Total & $53,112,615$ & 100.00 \\
\hline
\end{tabular}

Source: Croatian National Bank (2009).

The analysis of the market showed the similar situation to other transitioning countries because there was the continuation of the slowdown in the growth of bank assets size in relation to the previous years as the consequence of worsening economic and financial situation in the country and abroad in 2009. The negative economic trends were reflected in the low volume of lending due to reluctance by banks to increase their credit risk exposure and to a smaller demand for loans, in particular from households ${ }^{26}$. Moreover, bank lending activities in 2009 were much weaker than in previous years.

The image of the Croatian banking service sector has been negatively influenced by the crisis. The research conducted in Hungary, Romania, Serbia, Czech, Croatia, Poland, Slovenia and Bulgaria ${ }^{27}$ indicates that Croatian banks are rated the fifth as far as the bank image is concerned. The research showed that items related to cleanness were rated high, but services and customers' orientation were given the lowest mark.

\section{Sustainable development activities in the banking sectors in Poland and Croatia}

The popularization of the sustainable development idea led to the situation that banks which operate in Poland and Croatia strive to establish their market position by focusing their activities on all three aspects of sustainable development, i.e. they take into consideration ecology aspects as well as interests of a local community and their employees as a chance to succeed in the long term. The majority of banks signed the UNEP declaration, i.e. the declaration of banks concerned about the environmental protection and long-lasting sustainable development. Thus, they pledged to take into consideration the problems of environmental protection in 
their policy in the future. Following the declaration the banks have to observe standards of environmental protection, acknowledge the long-lasting and balanced development of the bank and its customers as the basis of its existence and the approval from the public ${ }^{28}$. Bank Ochrony Środowiska SA is a notable example of an institution which takes into consideration the idea of the sustainable development in its activities. The key component of the bank's mission is to contribute to environmental protection as its statute assumes the obligation to cooperate with ecological organizations. The bank has established and maintained lasting relations with the National Environmental Protection and Water Management Fund, regional environmental protection and water management funds, the Polish Countryside Development European Fund and other aid funds. The BOŚ President emphasizes that, according to the rule of the sustainable development, the bank strives for the active participation in the development of regions by supporting development programmes run by local-governments and entrepreneurs. The bank supports the Natura 2000 Programme and creates new forms of cooperation with environmental non-governmental organizations. It offers EKOKONTO and EKOPROFIT services (popular among customers) donating part of the profit to All-Poland Society of Birds Protection and Green Lungs of Poland Fund - organizations protecting various bird species.

In order to remain competitive in the ecologically aware world the banks apply an active environmental protection management system ${ }^{29}$. This system requires from banks to save energy, reduce paper use, make use of paperless cash turnover and offer environmentally-friendly banking. These activities also include offering preferential interest rates for credit borrowers who intend to use solar energy, or encouraging borrowers to apply environmentally-friendly management systems.

As the leading bank in Croatia, Zagrebačka banka has been continuously strengthening its profile as a bank focused on the three core areas of acting sustainably: environmental protection, social equality and responsible corporate management. In 1997, Zagrebačka banka joined forces of 17 leading Croatian companies in promoting the sustainable development concept in the Croatian economy based on the collaboration with the World Business Council for Sustainable Development. The main goal of the bank is to positively influence sustainability by protecting and conserving the natural resources through developing less resource intensive business practices and embracing opportunities for financial products and services that incorporate benefits for reduced environmental impact. Moreover, the bank encourages its employees to engage in effective waste management practices. The second largest Croatian bank, Privredna banka Zagreb, uses systems and equipment with low level of power consumption and high level of energy utilization. In accordance with environmental protection and waste disposal regulations, 
Privredna Banka is ensuring the disposal of dangerous and environmental endangering waste (such as toners, neon light tubes, etc.). All air condition systems use ecological gas and the power of all systems is reduced by using inverter technology ${ }^{30}$. OTP bank has set itself the goal of reducing our world-wide $\mathrm{CO} 2$ emissions $^{31}$.

Banks are actively involved in initiatives on social commitment. Most of them include developing relationships with their employees in their mission and their strategic goals - examples being PeKaO SA, PKO BP SA, Citi Handlowy SA, Fortis SA and Kredyt Bank SA in Poland. They strive to provide a pleasant and favourable working environment for their employees, and to maintain balance between their professional and personal lives. Banks also emphasize their aspirations to be perceived as the best employers in the banking sector. As a result of such measures, BOŚ bank was awarded the title of "The Solid Employer" for modern and ethical human resources management.

Social commitment of banks is demonstrated by supporting charities and maintaining good relationships with local communities. A large number of banks act directly by supporting financially the local community initiatives, by sponsoring cultural and artistic events, concerts, etc. Banks frequently establish their own charities. A case in point is the ING Foundation for Children whose aim is to equal chances by providing chronically ill children with education, by promoting business awareness among young people, and by helping young people from poor families gain access to higher education. This foundation also runs a programme called "In the company of a Lion" whose aim is to provide aid for children with cancer. This program was awarded in the Golden Clip 2005 competition in the category of Corporate Social Responsibility. Also Fortis Bank has established a foundation whose objective is to counteract social exclusion of children and young people. In 2008 the foundation entered into a strategic partnership with the Society of Children's Friends. Fortis Bank, like BRE Bank, has joined the Strategic Partners of the Responsible Business Forum.

Cause related activities are becoming increasingly popular among banks. Banks use affinity cards $\mathrm{s}^{32}$, i.e. credit cards where a certain amount of money (part of commission charged by a bank) is given to a charity every time the card is used. The affinity cards are issued with the approval of non-commercial organizations, and although the cards have their logos, they are not co-branded cards connected with loyalty programs. The affinity cards are issued for philanthropic purposes. Their holders are not entitled to discounts or other benefits. The only benefit is the satisfaction they derive from donating to charities. Although the donated amounts are quite low, they are paid on a regular basis. The affinity cards are offered by the following banks: PKO BP (the card supports the Program of Building Polish Artificial Heart), BISE, 
BPH, Bank Zachodni WBK, Polbank EFG (together with the Fund for Fulfilled Dreams) and Bank Millennium with WWF. Moreover, by means of the affinity cards banks appeal to their customers' emotions, their readiness to help others and their social sensitivity, thus strengthening bank-customer relationships based on trust.

Privredna Banka Zagreb is actively involved in a project - the workshops for citizens entitled "How to Balance Income and Expenditure" conducting free-of charge interactive workshops on managing personal finances to the general public. Also, for many years the Bank has been supporting an international program of student exchange and sponsor two one-year scholarships abroad every year. All other Croatian banks have been actively participating in a range of community projects and support financially charitable and social institutions, sports clubs and cultural institutions. Karlovačka banka conducted the humanitarian campaign "Save and give a gift" for the purpose of collecting the amount of 1 million kuna for the Children's Department of the Karlovačka hospital and the kindergarten. Međimurska Bank has been donating information equipment to institutions, sports clubs, schools, etc. This bank supports projects in the fields of culture, sport and science contributing in that way to the development of the community in which operates. Centar Bank is a member of the Croatian Olympic Pool and actively participates in financing Croatian sportsmen and sportswomen's preparations. There is a really impressing number of sponsorships and donation of banks in Croatia leading to the conclusion that sponsorship policy is the effective way for promoting a bank's brand name and for obtaining positive image of the bank. All banks in Croatia have well developed internal communication system, which is available to all their employees through Intranet. Additionally, Privredna Banka has got the internal magazine and the internal newsletter. It is important to point out that all banks are aware that motivated and satisfied employees are a key factor for the development of the bank. Therefore, all of them are constantly encouraging and motivating their employees through training, a friendly working environment, etc.

An economic dimension is a vital aspect of social responsibility of banks. In both countries banks declare that their priority is to establish lasting customer relationships in accordance with the code of ethics and the binding rules of conduct. These codes are called Rules of Good Bank Customs and are a set of rules relating to banks' activities. According to these rules, banks, being institutions of public trust, commit themselves to obey rules of professionalism, reliability, objectivity and conscientiousness. Banks should provide comprehensive information about services, terms and conditions of services provided, additional benefits, as well as bank charges and investment risks. However, what the banks declare differs from what their customers actually get. In many cases a declared attractive deposit does not translate into real benefits for 
customers. The specificity of a bank offer enables the banks to manipulate customers easily. The price of an offer is complex. Profit from a deposit depends not only on its nominal interest rate (the most distinctive parameter for customers), but also on the way in which interests are calculated or when they are paid. This information is often given in fine print as „footnotes marked with an asterisk" 33 . The interest rate does not always reflect the real value of an offer. Banks tend to use phrases such as 'up to $10 \%$ ', when such a rate is accessible only to a select group of customers, who are able to deposit considerable amount of money, or it refers to the last three months of a 12 month saving period. An average addressee of the offer is not informed about the existing threshold conditions. On the basis of the above examples it is possible to conclude that banks provide their customers with unreliable information, even though reliable information is to be one of the main tools used for creating the image of a trustworthy institution. Customers' trust in banks and the whole banking system suffers when they get insufficient information or no information at all about additional charges, or conditions to be satisfied in order to take advantage of bank special offers.

In Poland, the above-described practices were particularly noticeable in the autumn of 2008, when media started reporting the world's economic crisis. We must bear in mind, however, that ethical practices may determine the lasting customer confidence especially during a crisis. Customers soon started to receive banks' offers of attractive deposits. The Poles lost their trust in banks as a result of sudden toughening of terms and conditions of credits. Siwek and Sadowski ${ }^{34}$ divided banks into four groups:

1. Banks which introduced new rates or requirements regarding credit rating and down payment for all customers, i.e. both the new ones and the ones whose applications were being processed, and even those customers who obtained positive credit decisions. Such conduct of banks caused heavy losses for customers.

2. Banks, which changed the rules for customers whose applications were being processed, but offered them preferential terms.

3. Banks, which changed conditions instantly, but only for new customers.

4. Banks, which did not change conditions for customers whose applications, had already been registered, and gave time to new customers so that they could apply according to previous rules.

According to financial analysts, Bank Millenium was an example for the first group. At first, the bank decided to adhere to the previous rules of granting credits for credit applications, which were being processed. However, new rules applied to all customers who had not signed credit agreements (although they had obtained credit decisions) following a later decision. The new 
rules concerned an increase in compulsory down payment to $20 \%$ for mortgage loan in zlotys, and $30 \%$ for mortgage loans in foreign currency, an increase in margins, and the shortening of a mortgage loan period to 35 years. Nordea Bank acted in a similar way, although previous rules applied to those customers who obtained credit decisions, too. Polbank belonged to the second group. The bank divided its customers into three groups: customers who had received final decisions, customers who had received initial decisions, and those who had not received any decisions yet. As far as the first group was concerned, the bank adhered to the previous rules of granting credits; towards the second group the bank adhered to the rules of calculating the amount of credit, but changed price conditions; the third group was offered completely new conditions regarding the calculation of credit capacity (the amount of credit) and price conditions. This group comprised also mBank and Multi Bank, which introduced a smaller increase for customers whose applications were being processed, and a bigger increase for new customers. Among banks, which did not change the rules of granting credits for processed applications, were ING Bank Śląski, PKO BP and Reiffeisen Bank. Kredyt Bank and GE Money Bank were even more favorable to their customers. They did not change conditions for customers who had applied, and they also granted a transitional period for new customers, who could apply for credits on the same basis as before. As there was no analysis of banks behavior during the crisis in Croatia, only secondary data analysis gave suggestions that banks in Croatia belong to the first group of banks. In other words, with the development of crisis banks in Croatia introduced new rates or requirements regarding credit rating and down payment for all customers, i.e. both new and those whose applications were being processed, and even those customers who obtained positive credit decisions.

It is clear from the above facts that when making decisions about providing services during crisis the banks differ in terms of their concern for the customer and customer relationships. It can be assumed that the banks' behaviour will influence their future cooperation with customers and their decisions. Undoubtedly, the bank's behaviour in everyday situations, and especially in times of uncertainty, determines the customers' trust in banks. The banks which change decisions at the last moment signal to their customers that they do not deserve being trusted in.

On the basis of the above examples it is possible to conclude that banks are aware of the necessity of undertaking socially responsible activities. All activities by banks performed as a part of the social responsibility concept certainly strengthen their customer loyalty, and reduce their willingness to transfer to another bank, which is particularly important in times of the crisis and uncertainty on the market. Nevertheless, banks may fail in their efforts to support large-scale charity or ecological campaigns if they fail to maintain proper everyday contacts 
with their customers and act unethically. This has to be remembered especially during recession. Activities done as a part of sustainable development are effective if they are integrated and done skillfully.

\section{Methodology}

\subsection{The data}

The study focused on the banking sector in Poland and Croatia. In order to achieve as high response rate as possible, the study was conducted in the group of regional managers in those countries that were participating in Postgraduate studies at the Faculty of Economics and Management University of Szczecin and the Faculty of Economics and Business of Zagreb from February 2009 to June 2010. In total, 15 completed questionnaires from Poland and 18 completed questionnaires from Croatia were accepted for further analysis. The limited sample size is the main limitation of the study.

\subsection{The questionnaire design}

The questionnaire consisted of three sections: Section (1) devoted to environmental aspect of the banks' performance, Section (2) related to social aspect of the banks' performance, and Section (3) consisted the statements relating to the economic aspect of performance of the bank. The questionnaire also contained questions about the size of the banks and the years of its existence on the market.

The aspects of environmental responsibility in the banking institutions are presented by several following elements: generation of noise, smell of waste, existence and maintenance of fire-devices, etc. The questionnaire consists of 35 statements relating all aspects of environmental responsibility mentioned above. Statements have been adopted from A Guidelines Manual for Retailers towards Sustainable Consumption \& Production (2008). Statements relating to social and economic aspect of the banks' performance also come from the same source (there are 22 statements relating to all aspects of social responsibility and 6 statements focusing on the economic aspect of the banks' performance). For investigating the aspect of social responsibility in the banking such elements as: the exposure of banks' staff to temperature or noise extremes, policies on sick leave and/or maternity leave, staff training and updating of training, rewards programme for good performances, etc. were included. The economic aspect covered the decrease of unemployment in a local area, satisfying customers needs and the simultaneous obedience to the law and ethics, communication with customers, etc. 
A five-point Likert format was used to assess the level of commitments of managers to the various statements used in this section. The five-point scale ranged from $1=$ strongly disagree to $5=$ strongly agree.

\subsection{Analysis}

The collected data were analysed using SPSS. Except from the descriptive statistics calculations, testing the reliability with Cronbach's Alpha coefficient was conducted. Since data were not normally distributed, the Mann-Whitney $U$ test between the pair of groups was performed in an order to find out which of the groups were statistically significantly different from one another. The conventional significance level of 0,05 (p) was used.

\subsection{Results and discussion}

The sample mostly consists of large banks ( 83.3 percent of the sample), which have been operating for more than 12 years on the market. In order to find out the average perceptions of different aspects of the environmental, social and economic responsibility of banks included in the sample the descriptive statistics calculations were used. Table 3 shows the statements which have got the highest mean values for key sustainability dimensions.

Table 3. Average perception of different sustainable aspects (the highest mean values)

\begin{tabular}{|l|c|c|}
\hline \multicolumn{1}{|c|}{ Items } & Means & St. dev. \\
\hline Environmental dimensions: & & \\
we use off or reduced cooling after hours & 4.06 & 1.263 \\
we use natural lighting where possible & 4.00 & 1.299 \\
in our offices lights are off where not needed & 4.06 & 1.268 \\
\hline Social dimensions: & 4.79 & 0.485 \\
the perception of the noise levels by neighbours & 4.06 & 1.287 \\
policies on sick leave and/or maternity leave & 4.22 & 1.039 \\
staff training and updating of training & 4.09 & 1.331 \\
the developments of rewards programme for good performances & 4.25 & 1.047 \\
the development of internal communication system & 4.00 & 1.541 \\
the preventive health security of their employees & & \\
\hline Economic dimensions: & 4.33 & 0.957 \\
satisfying customers needs and the respect of low and ethic simultaneously & 4.24 & 1.146 \\
honestly communication with customers and giving them full information & 4.03 & 1.425 \\
\hline never hiding any information about an offer, prices etc. & & \\
\hline
\end{tabular}

Source: the authors.

The mean score for almost all the environmental aspects suggests environmentally irresponsible behaviour among the banks in Poland and Croatia. Namely, on the scale from 
1 to 5 , there are only three environmental items above 4.00 . However, the explanation of the companies' taking care about those environmental issues could be twofold and connected to cost reduction instead of environmental concerns. The analysis of the economic and social aspects of the sustainable development of banks shows that respondents are fully aware of the importance of those aspects of their performance.

Table 4. Statistically difference in sustainable development aspects between countries

\begin{tabular}{|c|c|c|c|c|c|c|c|}
\hline Items & Countries & $\mathrm{Md}$ & $\mathrm{n}$ & $U$ & $z$ & $p$ & $r$ \\
\hline $\begin{array}{l}\text { The use of ventilation by opening windows } \\
\text { instead of full air conditioning }\end{array}$ & $\begin{array}{l}\text { Poland } \\
\text { Croatia }\end{array}$ & $\begin{array}{l}4.5 \\
2.0\end{array}$ & $\begin{array}{l}14 \\
18 \\
\end{array}$ & 61.000 & -2.527 & 0.011 & 0.45 \\
\hline The installation of modern thermal windows & $\begin{array}{l}\text { Poland } \\
\text { Croatia }\end{array}$ & $\begin{array}{l}5.0 \\
3.0 \\
\end{array}$ & $\begin{array}{l}15 \\
18 \\
\end{array}$ & 74.500 & -2.297 & 0.022 & 0.40 \\
\hline Regularl control for dripping taps & $\begin{array}{l}\text { Poland } \\
\text { Croatia }\end{array}$ & $\begin{array}{l}5.0 \\
3.0\end{array}$ & $\begin{array}{l}15 \\
18 \\
\end{array}$ & 52.500 & -3.098 & 0.002 & 0.53 \\
\hline The rewards programme for good performance & $\begin{array}{l}\text { Poland } \\
\text { Croatia }\end{array}$ & $\begin{array}{l}5.0 \\
4.0\end{array}$ & $\begin{array}{l}15 \\
18 \\
\end{array}$ & 65.000 & -2.878 & 0.004 & 0.50 \\
\hline The level of internal communication system & $\begin{array}{l}\text { Poland } \\
\text { Croatia }\end{array}$ & $\begin{array}{l}5.0 \\
4.0 \\
\end{array}$ & $\begin{array}{l}14 \\
18 \\
\end{array}$ & 59.000 & -2.831 & 0.005 & 0.50 \\
\hline The adequacy of employees' wages & $\begin{array}{l}\text { Poland } \\
\text { Croatia }\end{array}$ & $\begin{array}{l}5.0 \\
3.0 \\
\end{array}$ & $\begin{array}{l}15 \\
17\end{array}$ & 68.000 & -2.351 & 0.019 & 0.42 \\
\hline $\begin{array}{l}\text { Running sponsorships and humanitarian } \\
\text { campaigns }\end{array}$ & $\begin{array}{l}\text { Poland } \\
\text { Croatia }\end{array}$ & $\begin{array}{l}5.0 \\
2.5 \\
\end{array}$ & $\begin{array}{l}15 \\
18 \\
\end{array}$ & 64.000 & -2.676 & 0.007 & 0.47 \\
\hline $\begin{array}{l}\text { Satisfying customers needs and simultaneous } \\
\text { respect for law and ethics }\end{array}$ & $\begin{array}{l}\text { Poland } \\
\text { Croatia }\end{array}$ & $\begin{array}{l}5.0 \\
4.0 \\
\end{array}$ & $\begin{array}{l}15 \\
18 \\
\end{array}$ & 84.000 & -2.072 & 0.038 & 0.36 \\
\hline Honest communication with the banks' clients & $\begin{array}{l}\text { Poland } \\
\text { Croatia }\end{array}$ & $\begin{array}{l}5.0 \\
4.0 \\
\end{array}$ & $\begin{array}{l}15 \\
18 \\
\end{array}$ & 43.500 & -3.711 & 0.000 & 0.65 \\
\hline $\begin{array}{l}\text { Providing complete information about an offer, } \\
\text { prices etc. }\end{array}$ & $\begin{array}{l}\text { Poland } \\
\text { Croatia }\end{array}$ & $\begin{array}{l}5.0 \\
4.0\end{array}$ & $\begin{array}{l}14 \\
18\end{array}$ & 65.500 & -2.553 & 0.011 & 0.45 \\
\hline
\end{tabular}

Source: the authors.

As sample consists of banks from two different countries, the Mann-Whitney U tests between the banks on the Polish and on the Croatian market was performed in order to find out which of the groups are significantly different according to all aspects of sustainable development (Table 4). It is obvious that the banks in Poland have realized the importance of the environment, as it is increasingly reflected in their strategies and daily business operations. In all three environmental items, the effect size (related to the difference between two observed groups, the Polish and Croatian banks) is moderate. Those environmental activities have increased their profitability while lowering costs and offering better quality in all business activities.

A Mann Whitney $U$ test also revealed statistically significant difference of the social impact that banks have on the society and on the communities within which they operate. Again, 
the banks in Poland expressed increasingly stronger need to take into account the environmental and social issues comparing to the banks in Croatia.

Concerning the last of the three key sustainability areas, the Mann-Whitney U tests between the pairs of groups showed that the banks in Poland have a wider range of economic impact than banks in Croatia. It is obvious that a medium to large effect size was considered ${ }^{35}$ in all cases.

Conclusively, all the analyzed aspects of environmental concern of banks suggest that the banks in Poland have stronger relationship with customer than the banks from Croatia and that employees in the Polish banks present stronger commitment to their clients. Therefore, the findings of this study are important for bank managers because they can give them directions on which areas they have to focus their business operations. Moreover, the findings suggest what are the areas where the banks' employee training programmes should be implemented.

\section{Conclusions}

Nowadays, it should be emphasised that companies focusing on profits often ignore ethical, social and environmental issues in their business. However, the development of the concept of sustainability makes them increasingly more focused on complying with standards of social, environmental and ethical responsibility. As confidence is the basic prerequisite of banks' operations, they are forced to obtain a long-term and high quality relationship with clients, their stakeholders, local communities in which they are active and their employees as well. Relations with bank customers and other institutions playing social functions are perceived as an effective way to create the bank's image, their customers' and other partners' trust and, consequently, to build their long term market position. Owing to this fact, banks tend to undertake activities aiming at creating a better society and a cleaner environment.

Unfortunately, the organisations often remember about the idea of sustainable development only in times of crisis and recession, in order to quickly restore their customers' confidence and boost their credibility. It should be noted, however, that achieving these benefits is only possible in the longer term. The banks' image, the way they are perceived by others are the result of actions carried out consistently over time. In this way the concept of sustainable development cannot be treated as a remedy to a temporary banks' failure. It should be well understood, planned and consistently implemented in the longer term. 


\section{Notes}

1 Goes et al. (2012), p. 405).

2 Bebbington (2001).

3 Hopwood et al. (2005), p. 38.

4 Stefanescu et al. (2009).

5 Montes (1998).

6 Hopwood et al. (2005), p. 38.

7 Knezevic et al. (2012), p. 3.

8 Ward (1962).

9 Kotler et al. (2002), p. 55.

${ }^{10}$ Żemigała (2007), p. 101.

11 WCED (1987), p. 43.

12 Stanley (2006), p. 100.

13 Roome, Bergin (2006).

${ }^{14}$ Lindfelt, Tornroos (2006).

15 Gołaszewska-Kaczan (2008), p. 497.

16 UNEP (2008).

17 Wąchol (2008), p. 359.

18 Szablewski (2007), p. 169.

${ }^{19}$ Law Gazette (1997).

${ }^{20}$ Polish National Bank (2012).

21 Pentor agency (2009).

${ }^{22}$ Podrug, Rašić Bakarić, Slijepčević (2007), p. 257.

${ }^{23}$ Croatian National Bank(2012), p. 6.

${ }^{24}$ Pavkovic, Obucina (2010), p. 1050.

${ }^{25}$ Croatian National Bank (2012), p. 5.

${ }^{26}$ Croatian National Bank (2010), p. 10.

27 www.monitor.hr/.

${ }^{28}$ Korenik (2002), pp. 97-98.

${ }^{29}$ Ibidem, p. 101.

${ }^{30}$ www.pbz.hr/.

31 www.otpbanka.hr.

${ }^{32}$ Drabarz (2007), pp. 1-2.

${ }^{33}$ Kowalczyk (2004).

${ }^{34}$ Siwek, Sadowski (2008).

35 Cohen (1988). 


\section{References}

Bebbington, J. (2001). Sustainable Development: A Review of the International Development, Business and Accounting Literature. Retrieved November 25, 2012, from http://papers. ssrn.com/sol3/papers.cfm?abstract_id=257434.

Cohen, J.W. (1988). Statistical Power analysis for the behavioral sciences, Hillsdale, NJ: Lawrence Erlbaum Associates.

Croatian National Bank. (2009, August). Banks Bulletin, 19.

Croatian National Bank. (2010, August). Banks Bulletin, 20.

Croatian National Bank. (2012, August). Banks Bulletin, 24.

50 biggest banks in Poland - 2010. (June 2010) Bank (pp. 6-11).

Drabarz, A. (2007). Serce $w$ portfelu, Retrieved October 25, 2010, from www.marketingnews.pl.

Goes, A.O.S., Brugni, T.V. \& Vervloet Fontes, M.J. (2012, November 21-22). Green Hotels: a one-way sustainable trip. In Trade Perspectives 2012: Trade in the Context of Sustainable Development, (pp. 398-413), Zagreb, Croatia: University of Zagreb.

Gołaszewska-Kaczan, U. (2008). Społeczna odpowiedzialność i zrównoważony rozwój przedsiębiorstwa. In: J. Bieliński \& M. Czerwińska (Eds.), Zarządzanie wartościa przedsiębiorstwa $w$ warunkach zakłóceń na rynkach finansowych (pp. 497-505). Sopot: Fundacja Rozwoju Uniwersytetu Gdańskiego.

Hopwood, B., Mellor, M. \& O’Brien, G. (2005). Sustainable Development: Mapping Different Approaches, Sustainable Development, 2(13), 38-52.

Knezevic, B., Sukser, B. \& Renko, S. (2012, November 21-22). Historical Aspects of Sustainable Development in Trade, In Trade Perspectives 2012: Trade in the Context of Sustainable Development, (pp. 1-18), Zagreb, Croatia: University of Zagreb.

Korenik, D. (2002). Konkurencyjność i konkurencja banków polskich od lat dziewięćdziesiątych XX wieku. Wrocław: Wydawnictwo Akademii Ekonomicznej we Wrocławiu.

Kotler, P., Armstrong, G., Saunders, J. \& Wong, V. (2002). Marketing, Podręcznik europejski. Warszawa: PWE.

Kowalczyk, A. (2004). Na granicy przyzwoitości. Bank, 3, 34-35.

Law Gazette (1997), 140, entries 938 and 939.

Lindfelt, L. \& Tornroos, J. (2006). Ethics and value creation in business research: comparing two approaches. European Journal of Marketing, 40 (3/4), 328-351.

Montes, L. (1998). Financing sustainable development in Mexico through alternative banks or "green banks", Journal of Project Finance, Spring, 67-72. 
Pavkovic, A. \& Obucina, A. (2010). The Influence of Financial Crises on Croatian Financial Structure. In: International Conference on Organizational Science Development "People and Organization", 24-26 March 2010 (pp. 1049-1058), Slovenia: Portorož.

Pentor agency. (2009). Changes in perception and image of Poland's banking sector'2009, Warszawa, April.

Podrug, N., Rašić Bakarić, I. \& Slijepčević, S. (2007). Identificiranje i analiza temeljnih kriterija za odabir banke u Hrvatskoj - ciljna skupina studenti, Zbornik Ekonomskog Fakulteta u Zagrebu, 5. 255-272.

Polish National Bank, www.nbp.pl (16 March 2012).

Roome, N.J. \& Bergin, R. (2006). Sustainable development in an industrial enterprise: the case of Ontario Hydro, Business Process Management, 12(6), 696-721.

Siwek, K. and Sadowski, J. (2008). Część banków oblała egzamin z fair play. Retrieved October 25, 2010, from www.e-banki.blogspot.com.

Stanley, S.R. (2006). Sustainable development in American planning: A critical appraisal. The Town Planning Review, 77(1). Retrieved November 25, 2012, from www.questia. com/library/p438753/the-town-planning-review/i2512281/vol-77-no-1-2006.

Stefanescu, A., Nisulescu, I., Vuta, M., Dudian, M. \& Duca, I. (2009). The Banking System, Integrated Part of the Sustainable Development. Retrieved November 25, 2012, from http:// papers.ssrn.com/sol3/papers.cfm?abstract_id=1347159.

Szablewski, A. (2007). Społeczny wymiar zarzadzania wartościa przedsiębiorstwa. In: E. Urbańczyk (Ed.), Strategie wzrostu wartości przedsiębiorstwa (pp. 169-175). Szczecin: Kreos.

UNEP (2008). Wuppertal Institute Collaborating Centre on Sustainable Consumption and Production. A Guidelines Manual for Retailers towards Sustainable Consumption \& Production. Retrieved October 30, 2010, from www.monitor.hr/vijesti/hrvatske-banke-dobro-izgledaju-ali-imaju-losu-uslugu/79681.

Wąchol, J. (2008). Nadzór korporacyjny w warunkach globalizacji a kodeks dobrych praktyk w aspekcie tworzenia wartości przedsiębiorstwa. In: J. Bieliński \& M. Czerwińska (Eds.), Zarządzanie wartościa przedsiębiorstwa $w$ warunkach zakłóceń na rynkach finansowych, (pp. 359-363). Sopot: Fundacja Rozwoju Uniwersytetu Gdańskiego.

Ward, B. (1962). The Rich Nations and the Poor Nations. New York: W.W. Norton and Company.

Word Commission on Environment and Development (WCED). (1987). Our Common Future, Oxford: Oxford University Press.

Żemigała, M. (2007). Społeczna odpowiedzialność przedsiębiorstwa. Kraków: Oficyna.

www.pbz.hr (30.10.2010).

www.otpbanka.hr (30.10.2010).

www.unep.org/GEO/geo3/english/045.htm (15.07.2012). 